\title{
豪展 望衰
}

\section{会長就任にあたって}

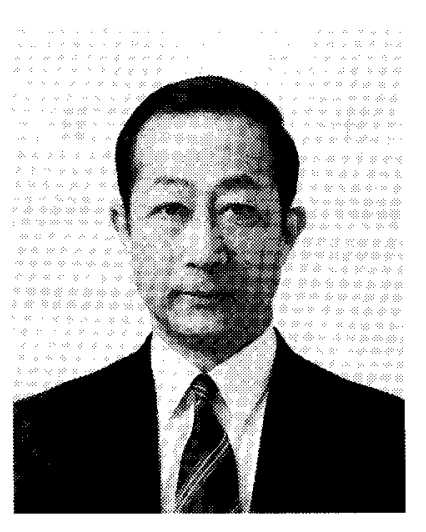

岸

Tomiya
富 也

KISHI

会長就任にあたって，一言ご挨拶申し上げます。

最近, 本会の活動は, 会員数の定常的な增加傾向, 大会における 発表件数, 参加者数の定着, 若手参加者の増加など, 大变活発であ ります．これらは，会員の皆樣のご協力によるところですが，先年 来の本会創立 60 周年の記念事業の成功之, 数年に亘る将来計画検 討委員会の活動に基づいた, 侌運営の改革に負うところが大きいと 考えられます。

本会は, その 60 年を超える歴史の中で, 産業構造の転換, 学問 の進展に対応して, 常に産学間の協力を軸に, 産学両分野に亘り, その発展に先導的な役割を果たしながら, 関連する分野を拡大して 参りました。これは電気化学の, 物理学と化学を結ぶ整った理論体 系之，それに内在する境界領域的性格の発現によるもの上考えられ, 今後さらに, 新たな分野への展開が期待されます。昨年, さらなる 発展を期して, 本会は会の名称を「電気化学会」に改めました。こ のことは, 本会にとって現在進みつつある社会の変革, 産業構造の 変化に対応して, 新たな産学間の協力の在り方を模索し, 社会への 貢献の幅を拡げるまたとない機会になると考えられます。

学会は，その活動の質が問われる時代を迎えました。本会にあっ ては, 支部活動と共に本会の活力の中心の一つである専門委員会, 研究技術想談会活動の新たな分野への展開, その従来にも増した柔 軟な活動, 運営が, 本会の特徽を活かし活性化する一つの方策之考 えられます。

新たな産業の発展の基となる新しい技術の芽を生み，それを担う 若手を養成していく上で, 研究者・技術者間——特に, 異分野, 異なる世代の一の直接の出会いの場を中心とした多元的な交流 の場は, 情報の汇濫, 多様化する昨今においてす, 極めて重要であ り，学会が, その主体的活動としてこのような場を設定することが 望まれます。

学会の 60 年は, 会員の学会活動とうておおよそ4世代に当たり, 現在は第 5 以降の世代が活動の中心であります，本会の懇談会の一 つである「蛍光体同学会」の呼称の例のように学会が同学の土の集 まりであることを原点とした若い世代の活躍に期待します.

会の益々の発展のため, 会員の皆様のご支援をお願い致します.

本会会長 慶應義塾大学理工学部（テ223 横浜门方港北区日吉 3-14-1） 